\title{
Assessing the Skills of Alberta's Refracting Opticians: Can Opticians Safely and Independently Refract and Prescribe Optical Appliances?
}

\author{
Alyssa Anderson, B.Sc. MPP \\ Alberta College \\ of Optometrists
}

Gordon Hensel, FAAO, OD

Alberta College

of Optometrists

\begin{abstract}
Alberta is one of three Canadian provinces that permits opticians to perform refractions. Recently, the Alberta College and Association of Opticians (ACAO) requested an expansion of opticians' scope of practice to include the ability to prescribe optical appliances, which is currently restricted to optometrists and ophthalmologists. For the remainder of this paper, the term "prescribe" should be interpreted as the prescription of an optical appliance, not a therapeutic pharmaceutical agent. In this paper, we investigate whether designated refracting opticians in Alberta have adequate training and knowledge to safely and independently perform a refraction and prescribe an optical appliance. To answer this research question, we composed a list of 27 skills we deemed necessary to safely and independently refract and prescribe. We then evaluated the Northern Alberta Institute of Technology's (NAIT) opticianry programs and the entry-to-practice examinations administered by the National Association of Canadian Optician Regulators (NACOR) and the Optometry Examining Board of Canada (OEBC) in terms of their coverage of these 27 skills. Our findings show that NAIT's optical science programs either do not cover or do not practically assess students on over half (59\%) of the skills required to safely and independently refract and prescribe, and the NACOR examination fails to cover $77 \%$ of these skills. Based on this information, refracting opticians in Alberta do not possess adequate training and knowledge to safely and independently perform a refraction and prescribe an optical appliance. Granting opticians the legislative authority to independently refract and prescribe may result in a public health issue, as there may be an increase in the number of undiagnosed or undetected eye and systemic diseases.
\end{abstract}

KEY WORDS:

Alberta, Optician, Optometrist, Refract, Prescribe, Training 


\section{INTRODUCTION}

Opticians are eye-care professionals trained to design, fit, adjust, and dispense optical appliances based on a prescription issued by an optometrist or physician. ${ }^{1}$ Alberta and two other Canadian provinces (B.C. and Ontario) have granted opticians with special certification the legislative authority to refract; however, no jurisdiction currently permits opticians to prescribe optical appliances.

In this study, we investigated whether refracting opticians in Alberta have adequate training and knowledge to safely and independently perform a refraction and prescribe an optical appliance. To safely perform a refraction and prescribe an optical appliance, an eye-care professional must possess the skills and knowledge to competently perform the task without causing a patient harm or injury. This research question is important because the Alberta College and Association of Opticians (ACAO) has requested an expansion of their scope of practice to include the legislative authority to prescribe. ${ }^{2}$ In Alberta, prescribing is considered a Restricted Activity. ${ }^{3}$ To ensure that the public is protected in an appropriate manner, only a regulated health professional with the appropriate skills, competencies, and knowledge may perform a specific Restricted Activity. Since optometrists have already been granted the Restricted Activity of prescribing, it may be helpful to compare opticians' refractionand prescription-related knowledge and skills to those of optometrists. This comparison will assist in determining whether Alberta's refracting opticians possess an appropriate skillset to safely and independently refract and prescribe without placing the public at undue risk.

METHODS

To answer this research question, we performed the following steps:

1) Compiled a list of key skills deemed to be necessary to safely and independently perform a refraction and prescribe an optical appliance

2) Evaluated the Northern Alberta Institute of Technology's (NAIT) optical science programs in terms of their coverage of these skills

3) Compared the entry to practice examinations administered by the National Association of Canadian Optician Regulators (NACOR) and the Optometry Examination Board of Canada (OEBC) in terms of their coverage of these skills

This paper describes the results of these activities and draws conclusions and provides recommendations on whether Alberta's refracting opticians possess adequate skills and knowledge to safely and independently perform a refraction and prescribe an optical appliance.

KEY SKILLS REQUIRED TO INDEPENDENTLY REFRACT AND PRESCRIBE

To safely refract and prescribe an optical appliance, an eye-care professional must review and/or assess five areas: ${ }^{4}$

- occupational/leisure activities and requirements,

- systemic health status,

- refractive status and visual acuities,

- binocular status, and

- ocular health status

It should be noted that to safely and independently perform a refraction and prescribe an optical appliance requires more than just the ability to determine a patient's refractive status and visual acuities. If factors such as ocular/ systemic health status, binocular status, or occupational/leisure considerations are not taken into account, the eyecare professional may place the patient at risk for the progression of undiagnosed ocular diseases or side effects from an inappropriate prescription (headaches or eyestrain). Therefore, safely and independently performing a refraction and prescribing an optical appliance requires skills and abilities beyond being able to simply perform the refraction itself. Table 1 outlines the 27 skills we deemed to be necessary to safely refract and prescribe according to the five areas listed above. 
Table 1: Key Skills Required to Safely Refract and Prescribe

\begin{tabular}{|c|c|}
\hline Area & Required Skills \\
\hline $\begin{array}{l}\text { Refractive Status } \\
\text { and Visual Acuities }\end{array}$ & $\begin{array}{l}\text { - Perform objective refraction using a retinoscope or autorefractor } \\
\text { - Perform subjective refraction using a phoropter or set of loose lenses } \\
\text { - Use distance and near acuity charts } \\
\text { - Use a keratometer to measure corneal curvature } \\
\text { - Measure lens power using a lensometer }\end{array}$ \\
\hline $\begin{array}{l}\text { Ocular Health } \\
\text { Status }\end{array}$ & $\begin{array}{l}\text { - Perform an anterior and posterior segment examination } \\
\text { - Use anterior and posterior photography equipment } \\
\text { - Use a scanning laser instrument } \\
\text { - Perform tonometry using a tonometer } \\
\text { - Perform a computerized visual field test } \\
\text { - Perform a color vision test } \\
\text { - Use a slit lamp } \\
\text { - Use an ophthalmoscope } \\
\text { - Use a penlight } \\
\text { - Use a pachymeter }\end{array}$ \\
\hline $\begin{array}{l}\text { Systemic Health } \\
\text { Status }\end{array}$ & $\begin{array}{l}\text { - Ability to detect signs of systemic disease on the eye and adnexa } \\
\text { - Ability to order lab tests } \\
\text { - Use an exophthalmometer } \\
\text { - Use a sphygmomanometer }\end{array}$ \\
\hline Binocular Status & $\begin{array}{l}\text { - Perform tests to assess binocular status } \\
\text { - Perform test to assess accommodative function } \\
\text { - Perform test to assess ocular motility } \\
\text { - Perform test to asses eye dominance } \\
\text { - Perform tests to assess eye commitance } \\
\text { - Perform tests to detect sensory disorders and other perceptual conditions }\end{array}$ \\
\hline $\begin{array}{l}\text { Occupational/ } \\
\text { Leisure Activities }\end{array}$ & $\begin{array}{l}\text { - Ability to understand patient needs } \\
\text { - Ability to communicate appropriate options to patient }\end{array}$ \\
\hline
\end{tabular}

An eye-care professional who performs refractions and issues prescriptions without the ability to perform all of these 27 skills may pose a significant public health risk. Next, these 27 skills were compared to 1) the skills and competencies taught in NAIT's three optical science programs and 2) the skills tested in the NACOR and OEBC entry-to-practice examinations.

\section{EVALUATION OF NAIT'S OPTICAL SCIENCE PROGRAMS}

NAIT is one of seven educational institutions in Canada that offers a NACOR-accredited optician education program (Table 2$).^{5}$

Table 2: Opticianry Programs Accredited by the National Association of Canadian Optician Regulators

\begin{tabular}{|l|l|}
\hline Educational Institution/Program & Location \\
\hline NAIT Optical Science Program & Edmonton, Alberta \\
\hline Seneca College Opticianry Program & Toronto, Ontario \\
\hline Douglas College Dispensing Optician Program & New Westminster, British Columbia \\
\hline Oulton College Optician Diploma Program & Moncton, New Brunswick \\
\hline $\begin{array}{l}\text { Community College of New Brunswick Eyewear and Contactology } \\
\text { Techniques Program }\end{array}$ & Moncton, New Brunswick \\
\hline Stenberg College Dispensing Optician Program & Surrey, British Columbia \\
\hline Georgian College Opticianry Program & Barrie, Ontario \\
\hline
\end{tabular}

Three colleges in Quebec also offer opticianry programs, but these programs are not accredited by NACOR. ${ }^{16}$ 
NAIT's optical science program is unique in that it offers a three-step system for the study of opticianry. In NAIT's system, students first pursue the Eyeglasses Diploma. ${ }^{6}$ Following this diploma, students may obtain specialized training by pursuing the Contact Lens Certificate and the Refraction Certificate.,8 Students in NAIT's programs must be working in the opticianry field with a licensed optician, optometrist, or ophthalmologist to oversee the practical component of each program.

We used NAIT's publicly accessible course outlines to investigate whether the 27 skills required to safely refract and prescribe are covered in the three optical science programs. Of the 27 skills we deemed to be necessary to safely refract and prescribe, NAIT's optical science programs cover and practically assess 11 (40.7\%), cover but do not practically assess 5 (18.5\%) and do not cover 11 (40.7\%) (Figure 1). Therefore, NAIT's optical science programs either do not cover or do not practically assess over half (59.2\%) of the skills required to safely refract and prescribe. Perhaps most significantly, NAIT's programs cover and practically assess only $20 \%$ of the skills required to assess ocular health (2/10) and none of the skills required to review/assess systemic health (0/4), while covering and practically assessing $80 \%$ of the skills required to assess refractive status (4/5).

Figure 1: Proportion of Refraction and Prescription-Related Skills Covered by NAIT's Optical Science Programs.

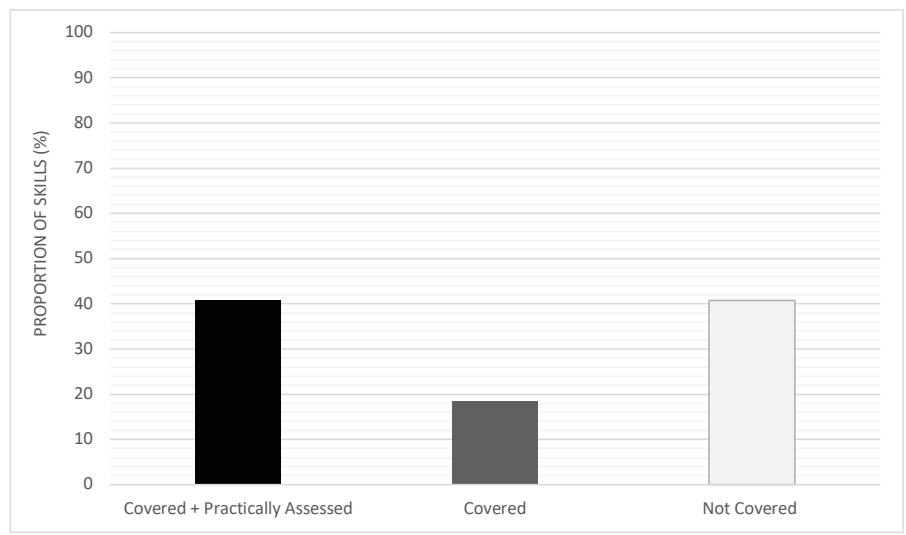

Figure 2 breaks down NAIT's coverage of skills according to the five areas required to safely refract and prescribe.

Figure 2: Proportion of Skills Covered by NAIT in the Five Areas Required to Safely Refract and Prescribe. Refer to Appendix A for a list of the specific skills that are covered, not covered, and practically assessed in NAIT's programs.

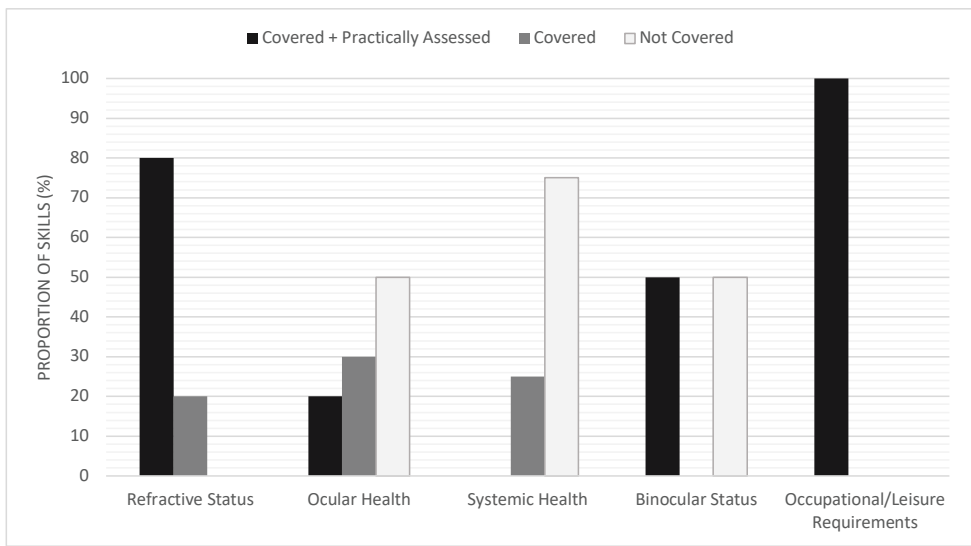


NACOR EXAM VS OEBC EXAM

NACOR is an independent regulatory authority that administers entry-to-practice examinations for opticianry. ${ }^{9}$ NACOR currently administers two examinations: the Optical Science 1 Eyeglasses Exam and the Optical Science 2 Advanced Practice Contact Lens Exam.

The OEBC is a not-for-profit organization that administers the entry-to-practice examination for optometry. ${ }^{10}$

The NACOR examinations cover $22.2 \%$ of the skills deemed to be necessary to safely and independently refract and prescribe an optical appliance (6/27 skills), while the OEBC exam covers $85.2 \%$ of these skills (23/27 skills) (Figure 3)..$^{11,12}$

Figure 3: Proportion of Refraction and Prescription-Related Skills Covered in the NACOR and OEBC Examinations. Refer to Appendix B for a list of the specific skills that are covered by the NACOR and OEBC exams.

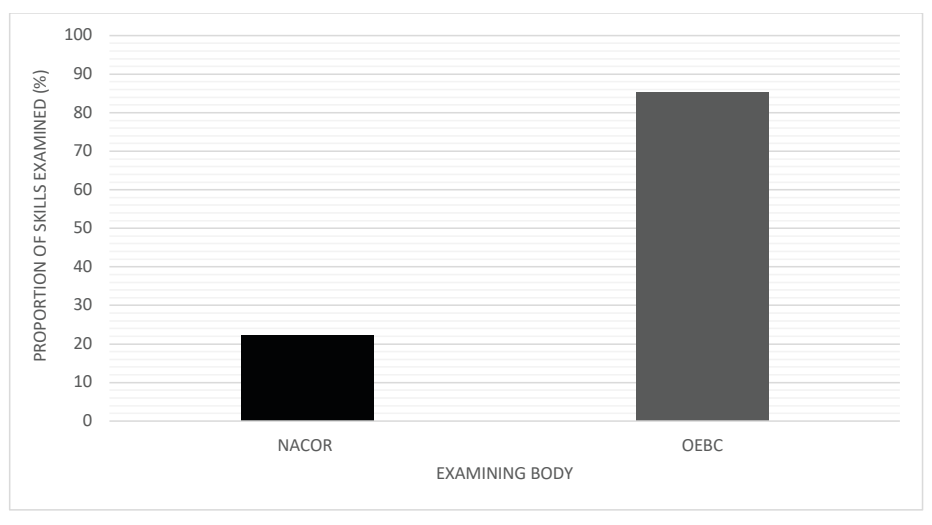

\section{DISCUSSION}

Refracting opticians in Alberta are trained to conduct refractions by completing NAIT's three opticianry programs, which do not cover or practically evaluate students on over half (59.2\%) of the skills we deemed to be necessary to safely and independently refract and prescribe (Figure 1). Most significantly, NAIT's programs do not adequately cover and practically assess what are arguably the most important of the five areas that we consider to be necessary to safely refract and prescribe an optical appliance (an individual's ocular health and systemic health), covering $20 \%$ and $0 \%$ of the requisite skills respectively, while covering and practically assessing $80 \%$ of the skills required to assess refractive status (4/5) (Figure 2). This suggests that NAIT's optical science programs successfully equip Alberta's refracting opticians with the skills required to perform a simple refraction, but fail to adequately cover and practically assess the skills that would be needed to fully inform the provision of a prescription. For this reason, we conclude that the training offered in NAIT's three optical science programs is not adequate to allow opticians to safely and independently perform a refraction and prescribe an optical appliance. However, given that the programs cover and practically assess four of the five skills required to assess a patient's refractive status, the training may be sufficient to permit refracting opticians to assess refractive status as but one component of a comprehensive eye exam performed by an optometrist or ophthalmologist.

We also found that the NACOR examinations do not examine candidates on $77.8 \%$ of the skills required to safely refract and prescribe (Figure 3), including the ability to perform objective and subjective refractions, binocular vision testing, and anterior and posterior segment ocular health examinations. Therefore, based on the content of the NACOR examinations, refracting opticians in Alberta are not adequately examined on the knowledge or skills required to safely and independently perform a refraction and prescribe an optical appliance.

Based on our analysis of the content covered in NAIT's optical science programs and the material tested in the NACOR examination, we conclude that refracting opticians in Alberta do not possess adequate training and knowledge to safely and independently perform a refraction and prescribe an optical appliance. Our findings point towards 
the potential for a public health issue. A 2014 study revealed that over 25\% of patients aged 19-64 presenting with solely refractive based symptoms were diagnosed with an asymptomatic eye condition. ${ }^{13}$ This study highlights the potential for a public health issue, as ocular health conditions presented by patients may go undetected and undiagnosed by refracting opticians. Alberta's aging population may also increase the number of eye-related conditions that could be overlooked by refracting opticians. Data obtained from Alberta Health Services (Appendix C) indicate that, between the fiscal years 2013/2014 and 2015/2016, a total of 487,066 eye-related diagnoses were made in Alberta. ${ }^{14}$ Further, in the 2014/2015 fiscal year, the Government of Alberta spent approximately $\$ 239.6$ million to treat eye-related diseases and disorders. The separation of refraction (let alone prescription) from ocular and systemic health assessment/review in Alberta may increase the risk that eye or systemic disease will remain undiagnosed or undetected. In turn, this may result in a higher incidence of avoidable vision loss and increased government spending on eye-care. Thus, from a public health standpoint, it is imperative that opticians should not be granted the legislative authority to independently refract and prescribe an optical appliance due to their lack of knowledge surrounding ocular health and binocular status.

Given that the Government of Alberta has already granted specially trained opticians the right to independently refract, and in light of the significant limitations identified in the current training and assessment of opticians, we recommend that NACOR develop a third entry-to-practice examination designed for opticians seeking the ability to independently refract. The examination should only be open to opticians in provinces that permit opticianperformed refractions (Alberta, B.C., and Ontario). Further, NACOR should work in collaboration with the OEBC to develop appropriate examination competencies and processes: if refracting opticians and optometrists both possess the legislative authority to refract, candidates in both fields should be examined similarly on their refraction-related skills. By developing a dedicated refracting optician examination, NACOR can ensure that opticians possess a more appropriate skillset to perform the refraction-related duties that currently fall under their scope of practice.

Incidentally, it should be noted that the OEBC examination failed to adequately assess four of 27 refraction- and prescription-related skills. Thus, we recommend that the OEBC amend their examination to cover all skills outlined in this paper.

We also recommend that NAIT alter the clinical portion of their Refraction Certificate. Currently, the clinical component of the Refraction Certificate can be supervised by a licensed optician, ophthalmic medical technologist, optometrist, or ophthalmologist. ${ }^{15}$ This difference in supervision could result in variability in students' learning outcomes. Therefore, it is recommended that NAIT standardize clinical supervisors to individuals who are most likely to possess a significant majority of the skills in question. With their breadth of clinical training, broad scope of practice, and experience performing refractions, licensed/registered optometrists best fulfill this criterion, which should reduce the potential for variability in student learning outcomes.

Our methods could be limited by a number of factors. First, the NAIT course outlines and NACOR and OEBC examination blueprints simply provide general overviews of the content taught and examined, respectively. Without auditing NAIT's courses or accessing NACOR's examinations, it is difficult to be certain about the exact content covered. Thus, our methods could be limited by the accuracy of the information in these documents. Second, our analysis was performed in accordance with the 27 skills that we deemed to be necessary to safely and independently refract and prescribe; however, this list may not be exhaustive, and any analysis of this kind may be prone to subjectivity as different eye-care professionals may view different skills as essential to safely refract and prescribe. Lastly, an ideal investigation of the skills and knowledge of Alberta's refracting opticians would have involved a controlled evaluation study. At the time of writing, a controlled evaluation study was not feasible. If, in the future, NAIT amends its course curriculum and NACOR amends its examination content to cover all the skills required to safely refract and prescribe an optical appliance, then a controlled evaluation study should be pursued. Notwithstanding these limitations, we conclude that the curriculum taught at NAIT and the competencies tested in the NACOR exams fail to provide refracting opticians with the appropriate skillset to safely and independently perform a refraction and prescribe an optical appliance. We are hopeful that future research can build off our study to further inform this important research question.

\section{CONCLUSION}

This study aimed to determine whether Alberta's refracting opticians possess an appropriate skillset to independently refract and prescribe in a safe manner. By analyzing the skills taught in NAIT's optical science programs and the competencies tested in the NACOR exams, we concluded that Alberta's refracting opticians do not currently possess the adequate skills and knowledge to safely and competently perform refraction and the Restricted Activity 
of prescribing. Thus, in the absence of significant enhancements to the training and assessment mechanisms currently in place, granting opticians the authority to prescribe would place the health of Albertans at risk by authorizing a Restricted Activity to a profession that is not equipped with the knowledge or skills needed to ensure that the public is not subjected to unnecessary risk.

CORRESPONDENCE

Dr. Gordon Hensel, OD. Email: registrar@collegeofoptometrists.ab.ca

\section{REFERENCES}

1. Alberta College and Association of Opticians. 2019. What is an Optician? https://acao.ca/public/about-opticians/what-is-an-optician/. Accessed October 3, 2019.

2. Alberta College and Association of Opticians. 2018. Annual Council Report. https://acao.ca/wp-content/uploads/2018/05/Final-DraftCouncil-Reports.pdf. Accessed October 28, 2019.

3. Government of Alberta. 2019. Government Organization Act RSA 2000 Chapter G-10 Schedule 7.1. http://www.qp.alberta.ca/documents/Acts/g10.pdf. Accessed November 12, 2019.

4. College of Optometrists of Ontario. 2016. Optometric Practice Reference. https://www.collegeoptom.on.ca/images/pdfs/030_iD_COO_ OPR_book_WEB.pdf. Accessed September 25, 2019.

5. National Association of Canadian Optician Regulators. 2019. Programs Accredited by NACOR. http://www.nacor.ca/Programs_Accredited_By_NACOR.aspx. Accessed October 28, 2019.

6. Northern Alberta Institute of Technology. 2019. Optical Sciences - Eyeglasses. https://www.nait.ca/coned/optical-scienceseyeglasses?term=2020-winter. Accessed October 28, 2019.

7. Northern Alberta Institute of Technology. 2019. Optical Sciences - Contact Lenses. https://www.nait.ca/coned/optical-sciencescontact-lenses?term=2020-fall\&overviewtabs=program-overview . Accessed October 28, 2019.

8. Northern Alberta Institute of Technology. 2019. Optical Sciences Refraction. https://www.nait.ca/coned/optical-sciences-refraction. Accessed October 28, 2019.
9. National Association of Canadian Optician Regulators. 2019 Organization. http://www.nacor.ca/Organization.aspx. Accessed October 28, 2019.

10. Optometry Examining Board of Canada. About OEBC. http://www. oebc.ca/about. Accessed October 28, 2019.

11. National Association of Canadian Optician Regulators. 2011. Can didate's Examination Handbook. http://www.nacor.ca/my_folders/ For_Candidates/Candidate\%27s\%20Examination\%20Handbook. pdf. Accessed October 28, 2019.

12. Optometry Examining Board of Canada. 2019. Current OEBC Exam Blueprint. http://www.oebc.ca/clientuploads/OSCE/Blueprint Written_+_OSCE_ENG_(website).pdf. Accessed October 28, 2019.

13. Michaud L, Forcier P. Prevalence of asymptomatic ocular conditions in subjects with refractive-based symptoms. J. Optom 2014;7(3):153-160. https://doi.org/10.1016/j.optom.2013.08.003.

14. Alberta Health Services. and Alberta Innovates. Data Snapshot of Health and Healthcare Utilization in Alberta. 2013. https://public.tableau.com/views/AlbertaVisitRatesDiagnosisRatesandCosts/DiagnosisRates?\%3Aembed=y\&\%3Adispl ay_count=yes\&\%3AshowVizHome=no. Accessed March 2, 2020.

15. Northern Alberta Institute of Technology. 2019. OPSC695 - Refraction Clinical Course Overview. https://www.nait.ca/nait/continuing-education/courses/opsc695-refraction-clinical. Accessed October 28, 2019. 
Table A1: NAIT's Coverage of Skills Required to Safely Refract and Prescribe.

\begin{tabular}{|c|c|c|}
\hline $\begin{array}{l}\text { Skill/Capability } \\
\text { Required }\end{array}$ & Related NAIT Learning Outcomes & $\begin{array}{l}\text { Practically } \\
\text { Assessed? }\end{array}$ \\
\hline Objective refraction & $\begin{array}{l}\text { - Explain objective refraction, including the purpose of a projector and trial lenses, } \\
\text { retinoscopy, phoropter and auto-phoropter, and ophthalmoscope } \\
\text { - Interpret the results of an objective refraction } \\
\text { - Explain and analyze the results of a refraction } \\
\text { - Use the autorefractor and retinoscope } \\
\text { - Demonstrate proficiency in comprehensive refraction with analysis and } \\
\text { interpretation of the test results } \\
\text { - Explain results of refraction to a patient } \\
\text { - Identify types of refraction procedures, including automated procedures }\end{array}$ & Yes \\
\hline Subjective refraction & $\begin{array}{l}\text { - Explain the principles and procedures of a subjective refraction } \\
\text { - Analyze the results of a subjective refraction and troubleshoot challenges } \\
\text { - Use the phoropter } \\
\text { - Perform subjective refraction } \\
\text { - Demonstrate proficiency in comprehensive refraction with analysis and } \\
\text { interpretation of the test results } \\
\text { - Explain results of refraction to a patient } \\
\text { - Identify types of refraction procedures, including subjective procedures }\end{array}$ & Yes \\
\hline $\begin{array}{l}\text { Distance and near } \\
\text { acuity charts }\end{array}$ & $\begin{array}{l}\text { - Explain vision screening, including visual acuity } \\
\text { - Perform visual acuity testing (near/far, with/without correction and pinhole acuity } \\
\text { testing) }\end{array}$ & Yes \\
\hline $\begin{array}{l}\text { Measure corneal } \\
\text { curvature }\end{array}$ & $\begin{array}{l}\text { - Evaluate cornea health using instrumentation, including keratometer readings and a } \\
\text { topographer }\end{array}$ & No \\
\hline $\begin{array}{l}\text { Measure lens power } \\
\text { using a lensometer }\end{array}$ & $\begin{array}{l}\text { - Analyze single vision and multifocal eyeglass parameters, including the power of a } \\
\text { lens at various meridians } \\
\text { - Interpret a single vision and a multifocal prescription, including lens power } \\
\text { - Evaluate contact lenses according to tolerances using a lensometer } \\
\text { - Calculate the curvature and power of a lens } \\
\text { - Measure the power of single vision eyeglass lenses } \\
\text { - Measure the power of multifocal lenses }\end{array}$ & Yes \\
\hline $\begin{array}{l}\text { Anterior and } \\
\text { Posterior Segment } \\
\text { Examination }\end{array}$ & $\begin{array}{l}\text { - Explain eye anatomy } \\
\text { - Explain eye physiology } \\
\text { - Recognize ocular pathologies in the internal layer, intermediate layer, external layer, } \\
\text { chambers, eyelid, and extraocular muscles } \\
\text { - Assess ocular health and counsel patients } \\
\text { - Assess ocular pathologies relating to contact lens wear on the eyelid and external } \\
\text { layer } \\
\text { - Differentiate diseases relating to contact lens wear }\end{array}$ & Yes \\
\hline $\begin{array}{l}\text { Anterior and } \\
\text { Posterior Segment } \\
\text { Photography } \\
\text { Equipment }\end{array}$ & - No related learning outcomes & $\mathrm{N} / \mathrm{A}$ \\
\hline Tonometry & - No related learning outcomes & $\mathrm{N} / \mathrm{A}$ \\
\hline $\begin{array}{l}\text { Computerized } \\
\text { Visual Field Test }\end{array}$ & - Explain vision screening, including visual field screening & No \\
\hline $\begin{array}{l}\text { Scanning Laser } \\
\text { Instrument }\end{array}$ & - No related learning outcomes & $\mathrm{N} / \mathrm{A}$ \\
\hline Slit Lamp & - Evaluate cornea health using a slit lamp & No \\
\hline Ophthalmoscope & - Explain objective refraction, including the use of an ophthalmoscope & No \\
\hline Penlight & - No related learning outcomes & $\mathrm{N} / \mathrm{A}$ \\
\hline Pachymeter & - No related learning outcomes & $\mathrm{N} / \mathrm{A}$ \\
\hline
\end{tabular}




\begin{tabular}{|c|c|c|}
\hline $\begin{array}{l}\text { Skill/Capability } \\
\text { Required }\end{array}$ & Related NAIT Learning Outcomes & $\begin{array}{l}\text { Practically } \\
\text { Assessed? }\end{array}$ \\
\hline Color Vision Test & $\begin{array}{l}\text { - Explain vision screening, including color testing } \\
\text { - Perform color vision testing }\end{array}$ & Yes \\
\hline $\begin{array}{l}\text { Detect Signs of } \\
\text { Systemic Disease } \\
\text { and Ocular } \\
\text { Conditions }\end{array}$ & $\begin{array}{l}\text { - Differentiate systemic diseases, including cardiovascular, endocrine, autoimmune, } \\
\text { infectious systemic, and neurological diseases } \\
\text { - Differentiate diseases relating to contact lens wear, including endocrine, } \\
\text { autoimmune, and systemic diseases }\end{array}$ & No \\
\hline Exophthalmometer & - No related learning outcomes & $\mathrm{N} / \mathrm{A}$ \\
\hline Sphygmomanometer & - No related learning outcomes & $\mathrm{N} / \mathrm{A}$ \\
\hline Order lab tests & - No related learning outcomes & $\mathrm{N} / \mathrm{A}$ \\
\hline $\begin{array}{l}\text { Assess } \\
\text { Accommodative } \\
\text { Function }\end{array}$ & $\begin{array}{l}\text { - Perform vergence testing, including accommodative function using crossed cylinder } \\
\text { test } \\
\text { - Assess accommodation using donders/push-up/proximity method and assess range } \\
\text { of accommodation }\end{array}$ & Yes \\
\hline $\begin{array}{l}\text { Perform Tests to } \\
\text { Assess Binocular } \\
\text { Status }\end{array}$ & $\begin{array}{l}\text { - Explain binocular vision testing including tropias, phorias, amblyopia, and binocular } \\
\text { vision syndromes and symptoms } \\
\text { - Perform muscle balance testing including Hirschberg corneal reflex test for eye } \\
\text { alignment, Krimshy corneal reflex test, and Worth Four-Dot test } \\
\text { - Perform testing for lateral and vertical phorias using Risley prisms } \\
\text { - Perform stereoacuity testing } \\
\text { - Perform subjective refraction, including binocular balance testing using prism } \\
\text { dissociation } \\
\text { - Explain vision screening, including ocular motility, binocular vision, pupil function, } \\
\text { and color testing }\end{array}$ & Yes \\
\hline $\begin{array}{l}\text { Assess Ocular } \\
\text { Motility }\end{array}$ & $\begin{array}{l}\text { - Explain physiology of the eye including extraocular muscles } \\
\text { - Perform muscle balance testing }\end{array}$ & Yes \\
\hline $\begin{array}{l}\text { Assess Eye } \\
\text { Dominance }\end{array}$ & - No related learning outcomes & $\mathrm{N} / \mathrm{A}$ \\
\hline $\begin{array}{l}\text { Assess Eye } \\
\text { Commitance }\end{array}$ & - No related learning outcomes & $\mathrm{N} / \mathrm{A}$ \\
\hline $\begin{array}{l}\text { Detect Sensory } \\
\text { Disorders/ } \\
\text { Perceptual } \\
\text { Conditions }\end{array}$ & - No related learning outcomes & $\mathrm{N} / \mathrm{A}$ \\
\hline $\begin{array}{l}\text { Understand Patient } \\
\text { Needs }\end{array}$ & $\begin{array}{l}\text { - Assess a prescription and determine patient needs to provide an optical appliance for } \\
\text { a patient } \\
\text { - Choose an appropriate single vision lens for a patient by analyzing the prescription } \\
\text { and determining patient needs } \\
\text { - Choose an appropriate multifocal lens for a patient by analyzing the prescription, } \\
\text { assessing patient needs, and selecting appropriate lens material and design }\end{array}$ & Yes \\
\hline $\begin{array}{l}\text { Communicate } \\
\text { Appropriate Options } \\
\text { to Patient }\end{array}$ & $\begin{array}{l}\text { - Explain the application of specialty appliances such as safety and sports eyewear } \\
\text { - Adapt communication/interaction techniques to enhance communication with } \\
\text { patients } \\
\text { - Counsel patients on single vision specialty appliances including safety eyewear and } \\
\text { sports eyewear }\end{array}$ & Yes \\
\hline
\end{tabular}


Table B1: NACOR and OEBC Exams' Coverage of the Skills Required to Refract and Prescribe

\begin{tabular}{|c|c|c|}
\hline Skill Required & NACOR Exam Coverage & OEBC Exam Coverage \\
\hline Objective Refraction & - Not covered & - Determine objective refraction using retinoscopy \\
\hline Subjective Refraction & - Not covered & $\begin{array}{l}\text { Determine distance subjective refraction } \\
\text { using a phoropter technique }\end{array}$ \\
\hline $\begin{array}{l}\text { Use Distance and Near } \\
\text { Acuity Charts }\end{array}$ & $\begin{array}{l}\text { Perform a routine } 6 \text { month follow up } \\
\text { examination on a live model (visual acuity } \\
\text { chart provided) }\end{array}$ & $\begin{array}{l}\text { Determine monocular and binocular aided } \\
\text { and unaided visual acuity at distance and } \\
\text { near }\end{array}$ \\
\hline $\begin{array}{l}\text { Measure Corneal } \\
\text { Curvature }\end{array}$ & $\begin{array}{l}\text { - Take the K-readings on one eye of a live } \\
\text { model }\end{array}$ & $\begin{array}{l}\text { - Determine corneal curvature using manual } \\
\text { keratometry }\end{array}$ \\
\hline $\begin{array}{l}\text { Measure Lens Power } \\
\text { Using a Lensometer }\end{array}$ & $\begin{array}{l}\text { - Neutralize lenses using a lensometer } \\
\text { Measure the back vertex power of soft } \\
\text { contact lenses and gas permeable lenses }\end{array}$ & $\begin{array}{l}\text { Verify parameters of vision enhancing and } \\
\text { corrective devices }\end{array}$ \\
\hline $\begin{array}{l}\text { Anterior and Posterior } \\
\text { Segment Examination }\end{array}$ & - Not covered & $\begin{array}{l}\text { Determine anterior and posterior segment } \\
\text { and ocular health status using fundus } \\
\text { biomicroscopy and direct and indirect } \\
\text { ophthalmoscopy }\end{array}$ \\
\hline $\begin{array}{l}\text { Anterior and Posterior } \\
\text { Segment Photography } \\
\text { Equipment }\end{array}$ & - Not covered & $\begin{array}{l}\text { Identify indications for fundus imaging, } \\
\text { corneal topography, optical coherence } \\
\text { tomography, Heidelberg retinal tomography, } \\
\text { and B-scan ultrasound }\end{array}$ \\
\hline Perform Tonometry & - Not covered & $\begin{array}{l}\text { Determine intraocular pressure using } \\
\text { applanation tonometry }\end{array}$ \\
\hline $\begin{array}{l}\text { Perform a Computerized } \\
\text { Visual Field Test }\end{array}$ & - Not covered & $\begin{array}{l}\text { - Identify indications for automated perimetry } \\
\text { testing }\end{array}$ \\
\hline $\begin{array}{l}\text { Use a Scanning Laser } \\
\text { Instrument }\end{array}$ & - Not covered & $\begin{array}{l}\text { - Identify indications for Heidelberg retinal } \\
\text { tomography }\end{array}$ \\
\hline Use a Slit Lamp & $\begin{array}{l}\text { - Set up, on the eye of a live model, any three } \\
\text { of the following slit lamp illuminations: } \\
\text { parallelepiped, specular reflection, direct } \\
\text { retro-illumination from the iris, sclerotic } \\
\text { scatter, and conical beam }\end{array}$ & $\begin{array}{l}\text { Determine anterior and posterior ocular } \\
\text { health status using biomicroscopy }\end{array}$ \\
\hline Use an Ophthalmoscope & - Not covered & $\begin{array}{l}\text { Determine anterior and posterior segment } \\
\text { and ocular health status using direct and } \\
\text { indirect ophthalmoscopy }\end{array}$ \\
\hline Use a Penlight & $\begin{array}{l}\text { - Measure the monocular distance and near } \\
\text { pupillary distance using a penlight }\end{array}$ & - Not covered \\
\hline Use a Pachymeter & - Not covered & - Perform pachymetry \\
\hline $\begin{array}{l}\text { Perform a Color Vision } \\
\text { Test }\end{array}$ & - Not covered & $\begin{array}{l}\text { Determine color vision status using Ishihara, } \\
\text { D-15 testing or Hardy Rand Ritter test }\end{array}$ \\
\hline $\begin{array}{l}\text { Ability to Detect Signs of } \\
\text { Systemic Disease }\end{array}$ & $\begin{array}{l}\text { - Identify various pathologies based on } \\
\text { photographs }\end{array}$ & $\begin{array}{l}\text { Demonstrate knowledge of signs and symptoms } \\
\text { of ocular or systemic medical conditions } \\
\text { requiring immediate attention }\end{array}$ \\
\hline Use an Exophthalmometer & - Not covered & - Not covered \\
\hline Use a Sphygmomanometer & - Not covered & - Not covered \\
\hline Ability to Order Lab Tests & - Not covered & $\begin{array}{l}\text { Identify indications for laboratory testing, } \\
\text { including cultures, blood testing, and medical } \\
\text { imaging }\end{array}$ \\
\hline
\end{tabular}




\begin{tabular}{|c|c|c|}
\hline Skill Required & NACOR Exam Coverage & OEBC Exam Coverage \\
\hline $\begin{array}{l}\text { Ability to Assess } \\
\text { Accommodative Function }\end{array}$ & - Not covered & $\begin{array}{l}\text { Determine the amplitude of accommodation } \\
\text { using push-up technique and Sheard's } \\
\text { technique }\end{array}$ \\
\hline $\begin{array}{l}\text { Ability to Assess } \\
\text { Binocular Status }\end{array}$ & - Not covered & $\begin{array}{l}\text { Determine ocular alignment using unilateral } \\
\text { and alternating cover tests } \\
\text { - Determine vergence reserves using prism bars } \\
\text { or rotary prisms } \\
\text { - Determine near point of convergence } \\
\text { - Determine vertical phoria using Maddox rod } \\
\text { and prisms }\end{array}$ \\
\hline $\begin{array}{l}\text { Ability to Assess Ocular } \\
\text { Motility }\end{array}$ & - Not covered & $\begin{array}{l}\text { Determine ocular motility using associated } \\
\text { broad } \mathrm{H} \text { testing }\end{array}$ \\
\hline $\begin{array}{l}\text { Ability to Assess Eye } \\
\text { Dominance }\end{array}$ & - Not covered & - Not covered \\
\hline $\begin{array}{l}\text { Ability to Assess Eye } \\
\text { Commitance }\end{array}$ & - Not covered & $\begin{array}{l}\text { Determine commitancy using the alternating } \\
\text { cover test }\end{array}$ \\
\hline $\begin{array}{l}\text { Ability to Detect Sensory } \\
\text { Disorders and Other } \\
\text { Perceptual Conditions }\end{array}$ & - Not covered & $\begin{array}{l}\text { - Assess sensory status using stereoacuity testing, } \\
\text { confrontation visual field test, color vision test, } \\
\text { Worth-4-Dot test, and Pelli-Robson test }\end{array}$ \\
\hline $\begin{array}{l}\text { Ability to Understand } \\
\text { Patient Needs }\end{array}$ & - Not covered & $\begin{array}{l}\text { Elicit patient values and preferences regarding } \\
\text { care }\end{array}$ \\
\hline $\begin{array}{l}\text { Ability to Communicate } \\
\text { Options to Satisfy Patient } \\
\text { Occupational/Leisure } \\
\text { Requirements }\end{array}$ & - Not covered & $\begin{array}{l}\text { - Provide counselling about ocular safety in } \\
\text { workplace and recreational applications }\end{array}$ \\
\hline
\end{tabular}

\section{Appendix C: Eye-Related Diagnoses and Healthcare Costs in Alberta}

Table C1: Eye-related diagnoses and costs in Alberta

\begin{tabular}{|l|c|c|}
\hline Type of Diagnosis & $\begin{array}{l}\text { Number of Diagnoses } \\
\text { (FY 2013/2014-2015/2016) }\end{array}$ & $\begin{array}{l}\text { Cost (millions of dollars in } \\
\text { FY 2014/2015) }\end{array}$ \\
\hline Chronic Eye Diagnoses & 204,461 & 83 \\
\hline Acute Eye Diagnoses & 13,895 & 14 \\
\hline Conjunctivitis and Other Eye Inflammation & 53,201 & 28 \\
\hline Glaucoma & 97,738 & 84 \\
\hline Cataract & 91,887 & 1.3 \\
\hline Amblyopia & 3,330 & 1.3 \\
\hline Blindness/Vision Loss & 6,609 & 13 \\
\hline Macular Degeneration & 15,945 & 239.6 \\
\hline Total & 487,066 & \\
\hline
\end{tabular}

Data were taken from Alberta Health Services' Data Snapshot of Health and Healthcare Utilization in Alberta. ${ }^{14}$ The cost associated with each diagnosis includes hospital-related costs (inpatient, emergency, and clinic) and direct physician billing. The number of diagnoses includes any diagnoses made between Fiscal Years 2013/2014 and 2015/2016. A single person may have received more than one diagnosis over this three-year period. 